\title{
THE FORMULATION AND REVIEW OF REGULATIONS UNDER THE FOOD, DRUG, AND COSMETIC ACT
}

\author{
RALPH F. FUCHS*
}

The new Food, Drug, and Cosmetic Act embodies the most drastic consequence thus far produced by a recent important tendency in federal legislation to impose strict procedural requirements upon regulatory agencies in the exercise of rule-making powers and to subject the resulting regulations to a high degree of judicial review. ${ }^{1}$ Heretofore the adoption of general regulations by administrative action, even where penal consequences attached to their violation, has not been surrounded by the safeguards that attend a judicial proceeding or an administrative proceeding of a "quasijudicial" character. ${ }^{2}$ Under the new Act, however, as under a number of other recent federal laws, ${ }^{3}$ the Secretary of Agriculture and his agents in the Food and Drug Administration are required to observe a careful procedure in devising numerous important regulations, and these regulations, in turn, are subject to judicial review in the Circuit Courts of Appeals. ${ }^{4}$ The resulting process resembles the previous machinery for prescribing public utility rates, rather than that employed in devising health and safety regulations, whether by the Food and Drug Administration itself or by other agencies. ${ }^{5}$

-A.B., 1922, LL.B., 1922, Washington University; Ph.D., 1925, Robert Brookings Graduate School; J.S.D., I935, Yale University. Professor, Washington University School of Law, St. Louis, Mo. Author of Procedure in Administrative Rule-Making (1938) 52 HARv. L. Rev. 259, and numerous other articles on administrative law and other legal subjects.

${ }^{2}$ Fuchs, Procedure in Administrative Rule-Making (1938) 52 HARv. L. REv. 259, 276-280. This tendency results partly from tine legislative desire to protect affected private interests, partly from judicial decisions that have tightened the application of the due process clause to rule-making procedure or have interpreted statutes as requiring procedural formalities, and partly from a tendency in recent professional thought to insist upon full safeguards to private interests in the exercise of rule-making, as of other, administrative powers. Thus the I937 report of the American Bar Association's Committee on Administrative Law recommended a requirement of notice and hearing in connection with all administrative rulemaking under statutes "affecting persons or property," together with judicial review of the resulting regulations in the Court of Claims upon a record to be made there. Existing methods of determining the legality of such regulations were also preserved. 62 A. B. A. REP. (1937) 807-821, 846-847. In the I938 report judicial review by the District of Columbia Court of Appeals was substituted. A. B. A. AdvanCE Program and Reports (1938) 166.

${ }^{3}$ Fuchs, supra note I, passim. ${ }^{3}$ See pp. $45-46$, infra.

- Pub. No. 717, 75th Cong., 3d Sess. (June 25, I938) §701, 52 STAT. 1055, 21 U. S. C. A. \$371 (Supp. 1938). (The text of the new Act as it will appear in the United States Code may be found in the 1938 Supplement to the United States Code Annotated. To avoid unnecessary repetition, reference to the Supplement will be omitted hereinafter in citing the Code section numbers of the Act.)

${ }^{-}$Fuchs, supra note I, $276-278$. 


\section{The Procedural and Review Provisions of the Act}

The procedural and review provisions of the new Food, Drug, and Cosmetic Act apply to those regulations, enumerated in the procedural section, ${ }^{6}$ which operate with regulatory effect in the sense that they must be observed by private enterprises in production or marketing which is subject to the Act. Comprising this class of regulations are those which the Secretary is authorized to promulgate in order to establish a reasonable standard of identity, quality, and fill of container for each class of food, ${ }^{7}$ those which may govern the labeling of dietary products, ${ }^{8}$ those which may be established for temporary periods to govern the production of food products liable to contamination by micro-organisms, ${ }^{9}$ those establishing limits of tolerance for the presence of unavoidable poisons added to food products, ${ }^{10}$ those which prescribe tests for the strength, quality, or purity of standard drugs, ${ }^{11}$ those which designate the habit-forming derivatives of narcotic drugs, ${ }^{12}$ those setting forth the statement of precautions to be included on the labels of drugs liable to deterioration, ${ }^{13}$ and those which provide for the listing of coal tar dyes for use in foods, ${ }^{14}$ drugs ${ }^{15}$ and cosmetics ${ }^{16}$ and for the certification of batches of such dyes. Exemptions from requirements of the Act which the Secretary is authorized to establish by regulation ${ }^{17}$ and other regulations, which do not directly control private activity, ${ }^{18}$ are not subject to the same procedural and review provisions.

The procedural requirements themselves are that the specified regulations be issued, amended, or repealed only after public hearings, following appropriate notice which sets forth the proposals to be acted upon, at which "any interested person may be heard in person or by his representative." Hearings must be called upon proposals emanating from an industry or substantial portion of an industry, stating reasonable grounds therefor. The Secretary shall by order announce his determination upon the proposals and "shall base his order only on substantial evidence of record at the hear-

\footnotetext{
- $\$ 70 I(e), 2$ I U. S. C. $\$ 37$ I (e). The violation of the restrictions contained in these regulations may entail seizure and condemnation of an offending product, $\$ 304,21$ id. $\$ 334$, liability to injunction proceedings $\$ 302,21$ id. $\$ 332$, or conviction of misdemeanor or felony, $\$ 303,21$ id. $\$ 333$.

I $\$ 401,403($ h $)$, 2 I U. S. C. $\$ \$ 341,343($ h). See p. 56 , infra.

${ }^{8} \$_{403}(\mathrm{j}), 2$ I U. S. C. $\$ 343(\mathrm{j})$.

$\$$ \$404(a), 21 id. $\$ 344(\mathrm{a})$.

$\mathrm{n}$ §501 (b), $2 \mathrm{r}$ id. $\$ 35 \mathrm{I}(\mathrm{b})$.

$23 \$ 502(\mathrm{~h}), 21$ id. $\$ 352(\mathrm{~h})$.

Is $\$ 504,21$ id. $\$ 354$.

II E.g., $\$ 403$ (i), 2 I U. S. C. $\$ 343(i)$, authorizing regulations to establish exemptions from the requirement of the Act that ingredients used in compounded food products be named on the label; $\$ 403(\mathrm{k}), 21$ id. $\$ 343(\mathrm{k})$, authorizing similar exemptions from the requirement that artificial flavoring, coloring, and preservatives in food products be specified on the labels; $\$ 403(\mathrm{e}), 21$ id. $\$ 343$ (e), $\$ 502(\mathrm{~b})$, 21 id. $\$ 352(\mathrm{~b})$, and $\$ 602(\mathrm{~b}), 21$ id. $\$ 362(\mathrm{~b})$, authorizing regulations to provide variations and exemptions from the requirement that quantities of food, drugs, and cosmetics in packages be accurately stated; $\$ 502(f), 21$ id. $\$ 352(f)$, authorizing regulations to exempt certain drugs from the requirement that directions for use be included on the label.

${ }^{33}$ These embrace regulations "for the efficient enforcement" of the Act, $\$ \$ 70$ (a) and (b), 2 I U. S. C: $\$ \$ 37 \mathrm{I}(\mathrm{a})$ and (b), and regulations governing the furnishing of portions of seized samples of foods, drugs, and cosmeties to the owners upon request, $\$ 702(\mathrm{~b}), 21$ id. $\$ 372(\mathrm{~b})$, as well as those under $\S 10 \mathrm{~A}$ of the former Act, 48 STAT. I204 (1934), 2I U. S. C. A. $\$ 3722$ (Supp. 1938), governing the certification of canned sea food by agents of the Department.
} 
ing and shall set forth as part of the order detailed findings of fact on which the order is based."19

Judicial review of the enumerated types of regulations may be had within 90 days of their issuance, amendment, or repeal, "in a case of actual controversy," by "any person who will be adversely affected." A petition for such review may be filed in the Circuit Court of Appeals for the circuit in which the plaintiff resides or has his principal place of business. Summons upon the Secretary of Agriculture may be had "at any place in the United States" and places upon him a duty "promptly ... [ [to] certify and file ... the transcript of the proceedings and the record on which the Secretary based his order." If the petitioner shows that additional evidence is material and that reasonable grounds existed for failure to adduce it in the administrative hearing, the court may remand the proceedings to the Secretary for the reception of such evidence and for possible modification of his action, followed by the return of the case to the court. In the court's review, "The findings of the Secretary as to the facts, if supported by substantial evidence, shall be conclusive"; but the court "shall have jurisdiction to affirm the order, or to set it aside in whole or in part, temporarily or permanently." Moreover, if the Secretary "refuses to issue, amend, or repeal a regulation" in disregard of law, the court shall order him "to take action . . . in accordance with law."20 Existing methods of judicial review of regulations are explicitly preserved by the Act. ${ }^{21}$

Other recent legislation contains procedural and review provisions which are not dissimilar to those in the Fcod, Drug, and Cosmetic Act, although they are somewhat less drastic and do not evidence the mistrust of the administrative authorities which Congress displayed in that act. The Fair Labor Standards Act, ${ }^{22}$ adopted at the same time as the food and drug measure, creates the office of Administrator and confers power upon him to establish wage rates for particular industries, departing within limits from the statutory standards. The appointment of industry committees in industries affected by the Act is required. Prior to any wage-variation order, the industry committee in the industry to which the order will apply must have made an investigation and submitted recommendations, upon which the Administrator must then have held a full hearing, followed by findings to support the order. There is no specific requirement that orders be based only upon evidence included in the record. ${ }^{23}$ The industry committees are entitled to rely upon their own knowledge ${ }^{24}$ and hearings are optional with them. ${ }^{25}$ There must, however, be evidence in the

\footnotetext{
${ }^{28} \$ 701(\mathrm{c}), 2 \mathrm{I}$ U. S. C. $\$ 37 \mathrm{I}(\mathrm{c}) .{ }^{20} \$ 70 \mathrm{I}(\mathrm{f}), 2 \mathrm{I}$ id. \$37I(f). $\quad{ }^{21}$ Id., par. (6).

29 Pub. No. 718, 75th Cong., 3d Sess. (June 25, x938), 52 Stat. 1060, 29 U. S. C. A. c. 8 (Supp. 1938 ). $3 \S 8,29$ U. S. C. $\$ 208$.

The committees are composed of representatives of the "public" and of employer representatives and employee representatives from within the industry, in equal numbers. Hence they are consultative as well as investigating bodies, designed to introduce first-hand knowledge into administration. See Fuchs, supra note $I$, at $274-275$.

25 The committees, or authorized subcommittees, "may, hear such witnesses and receive such evidence as may be neccssary or appropriate to enable the committee to perform its duties and functions." $\$ 8(\mathrm{~b})$, 29 U. S. C. $\$ 208$ (b). See also Regulations of the Wages and Hours Division, \$5I1.II, 3 FEd. REg. 2744, (Nov. 18,1938 ).
} 
record as it leaves the Administrator to support all findings of fact, for they may be rejected upon judicial review if not supported by substantial evidence. Such review may be had by "any person aggrieved" by an order and may result in the modification or setting aside of the order in whole or in part. In general, the court's review "shall be limited to questions of law."26

Under the Bituminous Coal Act of 1937 hearings must precede the issuance of all regulations that have "the force and effect of law." Such regulations must also be accompanied by findings of fact, which shall be conclusive upon judicial review, if supported by substantial evidence. ${ }^{27}$ Whether a statutory mode of judicial review has been provided, or whether non-statutory methods of review must be resorted to, is doubtful in the Act. ${ }^{28}$ Other recent legislation, although less clear-cut in its terms, contemplates the basing of administrative regulations upon data incorporated into a record, as well as provides for the judicial review of such regulations. ${ }^{20}$

It required more than a general legislative tendency, however, to produce the precise provisions of the Food, Drug, and Cosmetic Act which establish the procedure to be employed in the formulation of regulations and provide for the judicial review of such regulations. The Act has a history of its own which accounts for some of these terms. In the long struggle in Congress for more adequate food, drug, and cosmetic legislation following the introduction of the original Tugwell bill, ${ }^{30}$ there was a game of see-saw between the proponents of administration that should be equipped with teeth and advocates of the utmost opportunity for affected private interests to interpose objections to departmental regulations. The final outcome is a compromise between the two groups, into which, however, a last-minute assault by the representatives of the private point of view has incorporated certain provisions of new and doubtful import, together with language expressive of hostility toward the administration that supposedly was being strengthened.

The original bill ${ }^{31}$ contained no procedural or review provisions, thus leaving it open to the administration to work out its own methods ${ }^{32}$ and relying upon the "day in court" of affected parties when met by enforcement efforts, to furnish the necessary relief against misapplication of the law. The bill was met almost at once by a recommendation from the National Canners" Association that "a new section be

$20 \$ \mathrm{ro}(\mathrm{a}), 29$ U. S. C. $\$ 210(\mathrm{a})$.

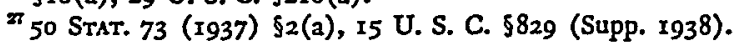

* The review provided by the Act itself extends only to "orders," but other means of reviewing regulations exist, such as injunction suits to prevent their enforcement. $\$ 6(\mathrm{~b})$, 15 id. $\$ 836(\mathrm{~b})$. See Saxton Coal Mining Co. v. National Bituminous Coal Comm'n, 96 F. (2d) 517 (App. D. C. 1938).

${ }^{20}$ E.g., Agricultural Adjustment Act of 1934, $58(\mathrm{c})(3),(4),(15), 49$ Srst. 754, 760, 7 U. S. C. A. $\$ 608 \mathrm{c}$ (Supp. 1938).

${ }^{0}$ S. I944, 73d Cong., Ist Sess. (1933). $\quad$ Ibid.

-See Fuchs, supra note I, for an account of various types of administrative rule-making procedure, upon which the Food and Drug Administration might have drawn. The I906 Act, 34 STAT. 768, 2i U. S. C. \$3, conferred no power to enact regulations, exeept such as were needed to control the routine of administration. Regulations of an advisory nature, intended to be observed by the industries affected, were usually preceded by informal hearings. Hays \& Ruff, The Administration of the Federal Food and Drugs Act (I933) I Law and Contemporary Problems, 16, 20-21. For the methods employed under the McNary-Mapes Amendment, 46 StaT. Iorg (1930), 21 U. S. C. §ro, "Foods," par. 5, see pp. 56.59, infra. 
added ... providing that in any regulation made, promulgated or prescribed under the Act, regulations and any evidence considered by the Secretary and any findings by the Secretary may be reëxamined by the courts as to questions of fact as well as law." ${ }^{33}$ Thus the two extreme positions were stated early in the game.

The original bill was supplanted by another draft ${ }^{34}$ in which both procedural and review provisions were included. These were not, however, of a particularly drastic character. Committees on public health and food, with membership chosen for technical competence, were established for the purpose of formulating proposed regulations when advised by the Secretary of the need of them. Public hearings were to be held by the Secretary upon these proposals and regulations were to be finally promulgated only with committee approval. ${ }^{35}$ A suit to restrain the enforcement of any regulation might be maintained if the petitioner could show that he would suffer substantial damage by reason of its enforcement and that the regulation was "unreasonable, arbitrary, or capricious or not in accordance with law." 38 The Secretary's findings of fact were to be conclusive. ${ }^{37}$ Later drafts of the bill provided for public health and food committees representative of the public, of the industries affected, and of the Food and Drug Administration; ${ }^{38}$ introduced a provision for industry advisory committees; and broadened the availability and scope of the judicial review of regulations. ${ }^{89}$ In the 74th Congress the pertinent provisions of a renewed bill ${ }^{40}$ underwent a similar metamorphosis. ${ }^{41}$ The bill was passed by the Senate with a provision for injunctions against the enforcement of regulations which were "not in accordance with the facts or the law." 42 In the House the Committee on Interstate and Foreign Commerce eliminated the provisions for public health and food committees and for judicial review, retaining a provision for hearings before the Secretary upon contemplated regulations. ${ }^{43}$ The measure failed of passage in the 74th Congress, however.

In the bill which finally became law the original Senate draft eliminated the device of committees to participate in the framing of regulations. It contained a provision for public notice and hearings upon proposed regulations and conferred authority upon the district courts to enjoin the enforcement of any regulation if it was "found as a fact or conclusion of law ... that the regulation is unreasonable, arbitrary, or capricious, or not in accordance with law and that the petitioner may suffer substantial damage by reason of its enforcement." ${ }^{44}$ Thus no specification was

\footnotetext{
* Annual Report of the Sectetary, National Canners' Association, for 1933, 56 Canning Trame no. 27, p. 15. Id. $\$ 22$.

${ }^{36}$ Id. $\$ 23$. ${ }^{8}$ S. 2000, 73d Cong., 2d Sess. (1934).

${ }^{*}$ Draft of Feb. 19, I934, 522(c); draft of the Senate Committee on Commerce, March 15, I934, $\$ 15(\mathrm{a})$

The Committee draft, supra note $38, \$ 22$, eliminated the clause conferring finality upon the Secretary's findings of fact. A later committee draft (May 16, 1934) provided that injunction proceedings might be brought by "any interested person" who could show that the regulation was "unreasonable in the light of facts" and that he might suffer damage.

"Amended Committee draft, March 22, 1935, $\$ 702,703(\mathrm{a})$.

S. 5, as passed by the Senate May 28, 1935, $\$ 702$.

4 Committee draft, May 22, 1936; H. REP. No. 2755, 74th Cong., 2d Sess., at 8.

u S. 5, 75th Cong., Ist Sess. $\$ \$ 24(\mathrm{e}), 30$ introduced, Jan. 6, 1937, passed March 9, 1937.
} 
made of the character of the administrative hearing, and judicial review was not made to include a reëxamination in court of the administration's factual conclusions except as they bore upon the possibility of a regulation's being unreasonable, arbitrary, or capricious.

In the House committee, to which the bill then went, considerably more stringent procedural provisions and an entirely different method of judicial review were substituted for those approved by the Senate. The requirement now in the Act, that all evidence be made a matter of record, ${ }^{45}$ was introduced. It was provided that a complaint, seeking either to enjoin the enforcement of a regulation or to compel its modification, together with service of summons, should be followed by the Secretary's certification of the transcript and record upon which his regulation was based. Thus review of the record was substituted for the consideration of a case against a regulation newly presented in court. No provision limiting the scope of review was included, but the court was authorized to enjoin the enforcement of the regulation, temporarily or permanently, and "to take such further action as justice may require." The power of review continued to be lodged in the district courts. ${ }^{46}$ The bill passed the House in this form.

As thus modified, the review provisions of the bill were more drastic than those included in any previous legislation with respect to administrative action of any kind. The combination of jurisdiction in the district courts, of judicial review on the basis of the administrative record, of unrestricted power to reverse the administrative determinations, and of authority to order affirmative action would have been overpowering. It evoked a storm of protest. In the conference committee the bill was changed to the present form of the Act, in which review by the Circuit Courts of Appeals is substituted for review in the district courts and the administrative findings of fact are made conclusive if supported by substantial evidence. ${ }^{47}$

\section{Background and Scope of the Procedurat and Review Provisions}

In thus subjecting the formulation of general regulations to detailed procedural requirements and providing for judicial review on the basis of the administrative record, the Food, Drug, and Cosmetic Act, even as modified in the conference committee, together with the other recent legislation previously noted, ${ }^{48}$ breaks fresh ground.

With respect to judicial review the terms of the new legislation stem principally from the provisions of the Federal Trade Commission Act, which provide for review of the Commission's cease-and-desist orders, both in enforcement proceedings brought by the Commission and in injunction suits filed by parties to whom such orders apply. The vesting of jurisdiction in the Circuit Courts of Appeals; the device of certification of the administrative record to the court; and the restriction of judicial

\footnotetext{
4 See p. 44, sutpra.

s. 5, 75th Cong., 3d Sess. $\$ 70 \mathrm{r}(\mathrm{c})$, (f), as reported to the House of Representatives by the Committee on Interstate and Foreign Commerce, April 14, 1938, \$70I(e), (f). H. R. REP. No. 2139, 75th Cong., 3 d Sess.

${ }^{17}$ See p. 45, supra.

${ }^{4}$ See pp. 45-46, supra.
} 
review to questions of law and to ascertaining the presence of evidence to sustain the administrative findings of fact were included in this relatively early legislation. ${ }^{40}$ With minor variations, the same provisions have been incorporated into numerous subsequent acts..$^{50}$

In most of the instances of the use of this formula derived from the Federal Trade Commission Act, however, the administrative acts thus subjected to judicial review were decisions and orders addressed to definite parties, as contrasted with administrative regulations of general application. For example, the Federal Trade Commission itself, the Board of Tax Appeals, and the National Labor Relations Board are not vested with rule-making functions except as regards their own procedure; their task is to deal with conditions as they find them in particular cases. Consequently the records which they certify into court when their decisions are called in question are more nearly of the variety with which courts are accustomed to deal, presenting fairly definite issues in regard to specific situations, than will be the case under the new Act.

With respect to procedure also, that which is prescribed for rule-making authorities in the Food, Drug, and Cosmetic Act and the other legislation mentioned above derives from sources which involve primarily administrative action that is addressed to specific parties. The theory that definite issues should be framed in an administrative proceeding and that all the evidence should be incorporated into a record so that it may be met by opposing parties, has been evolved by the courts, for the most part in public utility rate cases, as they have interpreted statutory provisions which require that a "fair hearing" be granted to affected parties.51 The requirement of adequate findings to provide a basis for judicial review, together with assurance that the statute has been followed, has come to be imposed through a similar process. ${ }^{52}$

${ }^{20} 38$ STAT. 719 (I914), I5 U.S. C. $\$ 45$. Similar provisions appear in the accompanying Clayton Act. 38 STAT. 734 (1914), I5 U. S. C. \$2I.

${ }^{\omega}$ Board of Tax Appeals, 45 STAT. 872 (I928), 26 U. S. C. \$6I7(b), 44 STAT. I09, Iro (I926), 26 U. S. C. $\$ \$ 641,642$; Securities and Exchange Commission, 48 STAT. 80 (I933), I5 U. S. C. \$77i, 48 STAT. 901 (1934), I5 U. S. C. $\$ 78 y$, 49 STAт. 834 (1935), I5 U. S. C. \$79x; Federal Communications Comm'n, 48 Stat. 1093 (1934), 47 U. S. C. $\$ 402$; Nat. Labor Relations Bd., 49 STAT. 453 (1935), 29 U. S. C. §I60; Civil Aeronautics Authority, 52 STAт. 1024 (1938), 49 U. S. C. $\$ 646$. An alternative means of review, by proceedings in the district courts to enforce or enjoin the enforcement of an administrative order, without statutory provision for certification of the administrative records or statutory prescription of the scope of the review, has been carried forward from statutes applicable to orders of the Interstate Commerce Commission. See, e.g., Federal Communications Comm'n, 48 STAT. 1093 (I934), 47 U. S. C. $\$ 402$ (a).

a Hanft, Utilities Commissions as Expert Courts (1936) 55 N. C. L. Rev. 12; Ohio Bell Telephone Co. v. Public Utilities Comm'n, 301 U. S. 292 (1937). Recently the celebrated cases of Morgan v. U. S., 298 U.S. 468 (1936), 304 U. S. I (1938) dealt, in part, with the requirement that issues be framed prior to the decision in a rate proceeding so as to give opportunity for argument upon them. See (1938) 33 ILL. L. Rev. 325, for a review of the cases. Compare Nat. Labor Relations Bd. v. McKay Radio \& Tel. Co., 304 U. S. 333 (1938). As to the requirement that the evidence be disclosed to the applicant in a licensing proceeding, see Bratton v. Chandler, 260 U. S. I Io (I922). Numerous cases hold that in various situations these procedural requirements do not apply. The purpose here, however, is to indicate the history of the requirements.

w Wichita Power \& Light Co. v. Public Utilities Comm'n, 260 U. S. 48 (1930); Beaumont, S. L. \& W. R. Co. v. U. S., 282 U. S. 74,86 (1930); Florida v. U. S., 282 U. S. I94 (I93I); U. S. v. C. Mf. St. P. \& P. R. Co., 294 U. S. 499 (1935). 
The new Food, Drug, and Cosmetic Act simply writes into the statute the details of these previously developed judicial doctrines-and does so in connection with rulemaking powers to which the doctrines originally had no application. The legislative inclination to enact such an extension of procedural requirements no doubt was strengthened by two decisions in which the Supreme Court itself effected a similar extension of the requirement of findings. In Panama Refining Co. v. Ryan ${ }^{58}$ it held that executive regulations enacted in the exercise of a broad delegated discretion, whose violation entails criminal penalties, must as a matter of due process of law be accompanied by findings, in order that the authority for the regulations may sufficiently appear. In United States v. B. \& O.R. Co. ${ }^{54}$ it held that a regulation of the Interstate Commerce Commission under the Boiler Inspection Act, requiring the installation of power reverse gears on locomotives of more than a certain weight, could not stand without "the basic or essential findings necessary to support the Commission's order." A mere finding that the specified locomotives "should have" such gears was held to be insufficient. Here the Court, having previously resorted to doubtful inferences in order to confer the power to impose general regulations under the Boiler Inspection Act ${ }^{55}$ upon the Commission, ${ }^{56}$ indulged the further inference that the Interstate Commerce Act's requirement of a report stating "the conclusions of the Commission," to accompany each order except in reparations cases, ${ }^{67}$ applied also to an order imposing a safety regulation. Since in practice the Commission had followed the equivalent of its rate-fixing procedure in arriving at its order, $^{68}$ the Court's conclusion was not unnatural. It is but a short step from the assumption that certain procedural requirements apply in the formulating of safety regulations to the enactment of similar mandatory requirements in new statutes conferring rule-making powers.

There can be little doubt of the intention of the legislative sponsors of the present procedural and review provisions of the Food, Drug, and Cosmetic Act to secure complete adherence to the stricter requirements of the foregoing authorities. Mr. Lea, Chairman of the House committee in charge of the bill, assured the Representatives that the measure "in substance provides that the legislative agency shall do the very things that the Supreme Court said they should do in the Morgan case" and that the judicial review section "means an honest-to-God review by the court for the purpose of performing the function of protecting the law against the legislative or the executive departments of the Government." ${ }^{\text {"9 }}$ The committee report itself referred to the Ohio Bell Telephone Company case as authority for the procedural requirements contained in the House bill ${ }^{80}$ and stated that the provision. for judicial

${ }^{2} 293$ U. S. 388 (1935).

$\approx 36$ STAT. $9{ }_{3}$ (r924), 45 U. S. C. \$22ff.

* 293 U. S. 454 (I935).

${ }^{6}$ Napier v. Atlantic Coast Line R. Co., 272 U. S. 605 (1926).

or 34 Stat. 589 (I906), 49 U. S. C. \$14.

* Johnson v. Atlantic Coast Line R. Co., I90 I. C. C. 351 (1933). The Commission frequently applies its formal procedure in formulating safety regulations. 3A Sharfman, The Interstate Commerce ComMrssion (I935) p. 56.

${ }^{8} 83$ Cong. Rec. II 830 (June 13,1938 ).

${ }^{\infty}$ H. R. REP. No. 2139, 75th Cong., 3 d Sss. (1938) ro. The case is cited supra note 51. 
review was designed to leave the court free "to exercise its review to the full extent that it may constitutionally do so." ${ }^{81}$ This statement applies almost equally to the present provisions of the Act.

\section{Relation of Provisions to Administrative Prockedure in Gengral}

The foregoing statutes and decisions are far from conveying a picture of the procedures that prevail in the numerous instances in which administrative authorities exercise rule-making powers. Statutes conferring such powers usually are silent in regard to the procedure to be employed; administrative practice varies widely; and judicial decisions with respect to the appropriate procedure are relatively few in number. ${ }^{\circ 2}$ Hence the Food, Drug, and Cosmetic Act, in common with the recent tendency toward procedural strictness which it exemplifies, represents a distinct departure from prevailing standards. This deviation results either from a supposed analogy to "quasi-judicial" administrative functions, from the pressure of private interests upon legislatures and courts, or from both.

Frequently the cases that have dealt with the matter have drawn an analogy between administrative rule-making and the action of the legislature, because the normal product of both is a rule of general, and of future, application. Hence it has been held that a hearing, if not required by statute, is not necessary in connection with the formulating of regulations ${ }^{63}$ or that the hearing, if required, may be of the informal character which is usual in legislative committee investigations. ${ }^{\text {st }}$ Neither the observance of the rules of evidence, the confinement of the basis of administrative action to evidence adduced at a hearing, the making of a rocord of the proceedings, nor the formulation of findings to accompany a regulation would be necessary under such a conception. The Supreme Court itself, in a decision ${ }^{65}$ following the Panama Refining case, quickly held that findings need not accompany an administrative regulation which is an exercise of delegated "police power"se and which is "general legislation, not an administrative order in the nature of a judgment directed against an individual concern."

In judicial review of regulations also, the courts have usually limited their own competence to a rather narrow range. The typical method of obtaining a review has been by means of resistance to a prosecution for violation or by a suit to enjoin the enforcement of a regulation. If a record of the administrative proceeding that led to the regulation comes before the court in such a case, it is simply as part of the evi-

Id. at 12.

- Fuchs, supra note I, passim.

- State v. Quattropani, 99 Vt. 360, 133 At. 352 (1925); State Board of Milk Control v. Newark Milk Co, 118 N. J. Eq. 504, 179 Atl. II6 (x935).

"Normegian Nitrogen Products Co. v. United States, 288 U. S. 294 (1933); Highland Farms Dairy v. Agnew, 16 F. Supp. 575 (E. D. Va. 1936).

-Pacific States Box \& Basket Co. v. White, 296 U. S. I76 (1935).

- The regulation in question was promulgated by the Department of Agriculure of the State of Oregon, after 2 hearing, and established the dimensions and certain characteristics of standard strawberry and rasperry cantainers. Following the regulation, it became 2 misdemennor to use containers not conforming to the prescribed standard.

- Pacific States Box \& Basket Co. v. White, 296 U. S. 2t I86. 
dence bearing upon the issues. ${ }^{08}$ In the absence of a record, there may be "nothing to show the grounds" upon which the administrative action was based. ${ }^{00}$ With or without an administrative record, the question for the court is simply whether "any state of facts can reasonably be conceived that would sustain" the regulation. If so, a presumption arises that such.a state of facts actually exists. ${ }^{70}$ Stated otherwise, the court will inquire solely whether the regulation is arbitrary and capricious ${ }^{71}$ or not in accord with law or not within the jurisdiction of the authority adopting it. ${ }^{22}$

The question naturally arises whether the more formal requirements imposed by the Food, Drug, and Cosmetic Act are reasonably applicable to an administrative function that is in many respects unlike the granting or revocation of a license, the decision of a workmen's compensation case, the issuance of a cease-and-desist order against a single respondent, the entry of an order to abate an unhealthful condition, the granting of a certificate of convenience and necessity, or the fixing of rates for one or a few utilities. In all of these instances the administrative action involves the determination of issues relating to a fairly definite transaction or state of affairs. These issues can usually be stated with some precision; the relevance to them of offered evidence can be determined in accordance with accustomed logical methods; the parties entitled to be heard can be identified fairly easily; findings can be stated with some definiteness and a decision related to them; and judicial review can center successfully upon the essential points. Each exercise of the rule-making authority which reposes in the Secretary of Agriculture under the new Act, on the other hand, relates to a general condition or to practices in which multitudes of individuals and of transactions are involved. The investigation must range over a wide field and the administrative decision must deal more largely with probabilities and less with established facts than in connection with the other types of functions.

- The foregoing differences are to some extent differences in degree rather than in kind. The probable behavior of a licensee if his application for a permit or a certificate is granted, like the business effects of a given utility rate, depends upon future contingencies-although in other instances of "quasi-judicial" administrative action, such as nuisance abatement and the decision of workmen's compensation cases, past facts very largely determine the decision.

Undeniably the same analysis of the processes involved in reaching official de-

${ }^{\infty}$ See Fuchs and Freedman, The Wagner Act Decisions and Factual Technique in Public Law Cases (1937) 22 WAst. U. L. Q. 510, and works there cited for analyses of the problem of introducing factual material bearing upon issues of law, such as the legality of a regulation, as distinguished from issues of fact, in a case. Compare Marshall v. Dep't of Agriculture, 44 Idaho 440,258 Pac. I71 (1927).

${ }^{\infty}$ See Southern Ry. Co. v. Virginia, 290 U. S. 190, I99 (1933); Oklahoma Operating Co. v. Love, 252 U. S. 33 I (1920). Independent testimony in court may, however, reveal the basis of the administrative action quite thoroughly. Sec Houston v. St. Louis Independent Packing Co., 249 U. S. 479 (1919).

${ }^{70}$ Pacific States Box \& Basket Co. $v$. White, supra note 65 . The question is the same in a case in which the validity of a municipal ordinance is called in question. City and County of San Francisco v. Market Street Ry. Co., 98 F. (2d) 628 (C. C. A. 9 th, 1938).

${ }^{1}$ Herrin v. Arnold, 82 P. (2d) 977, 982 (Okla. I938); People v. McGinley, 329 Ill. 173, I6o N. E. 186 (1928); Wallace v. Feehan, 206 Ind. 522, 190 N. E. 438 (1934).

z U. S. v. United Verde Copper Co., I96 U. S. 207 (1905); Waite v. Macy, 246 U. S. 606 (1918); U. S. v. Johnson, 35 F. (2d) 356 (D. Nev. 1929). 
cisions may be applied both to rule-making and to the disposal of specific cases of various kinds. Whenever it must be decided whether certain circumstances call for an order or decision of one kind or another, it is necessary (I) to frame certain issues of fact, or state certain hypotheses, involved in the matter in hand; (2) to obtain information, or evidence, bearing upon these issues; (3) to arrive at conclusions with regard to them; and (4) to reach a decision in the light of these conclusions, upon the basis of (a) directions contained in the governing statute and (b) the exercise of whatever discretion rests with the deciding authority. ${ }^{73}$ Judicial review of an official decision may involve a complete or partial check upon some or all of these processes.

The problems with respect to rule-making under the Food, Drug, and Cosmetic Act are (I) whether the foregoing essential processes can be formalized with suffcient success to justify the statutory command that all evidence be made of record, that findings of fact be stated upon the basis of the record alone, and that the order embodying a regulation be based upon these findings, and (2) whether the authority conferred upon the courts to judge the substantiality of the supporting evidence and where necessary to order such administrative action as the law seems to them to call for can be beneficially exercised. Certain subsidiary questions of constitutionality, of the availability of judicial review, and of the effect of judicial decrees need also to be considered.

\section{The Probable Operation of the Procedure and Review Provistons}

Three classes of regulations to which the procedural requirements of the Act apply may be distinguished for the purpose of this discussion. These are (I) regulations based upon scientific determinations, such as the ascertainment of the habit-forming properties of narcotic derivatives; (2) regulations based upon an appraisal of the qualities of products in terms of human estimation of them, such as the establishment of standards of identity and quality for classes of foods; and (3) regulations which take account of psychological effects, such as those which govern labels and directions for the use of products. Different investigational techniques seem to be called for in connection with these three classes. Their relation to the legally-prescribed procedure and to review by the courts presents the essential problem.

Although a scientific investigation of the properties of a given substance does not proceed by the methods laid down in the Act for the formulating of administrative regulations, it is susceptible to reduction to these methods. The issues seem capable of fairly simple and definite statement; the results of the investigation can be set forth in evidentiary form; findings can be made with reasonable definiteness; and a conclusion can be based upon the findings. Upon judicial review the lay mind of the judge probably can grasp the essentials of the reasoning involved and detect nonsequiturs, although judicial attempts to substitute the conclusions of the courts for those of the administrative authorities would be certain to create diffculties. ${ }^{74}$ The

${ }^{73}$ Sec Saginaw Broadcasting Co. v. Federal Communications Comm'n, 96 F. (2d) 554, 559 (App. D. C. 1938 ).

"See the discussion of the constitutionality of judicial prescription of affirmative action, infra, pp. 65-66. A scientific investigation of a different sort, involving non-experimental methods of ascertaining 
regulations involving this type of determination are not likely to present excessively difficult problems of a procedural nature in the administration of the Act. The necessity of suffering the delay and expense connected with notice, hearing, and judicial review represents the principal drawback from an administrative standpoint. Whether this drawback is counterbalanced by compensating safeguards to public and private interests through the reduction of the evidence and reasoning to definite form and through the judicial check is perhaps open to question. A recent example of reasoning based on inadequate data under the still-subsisting prior Act, which doubtless was perpetrated unwillingly under the pressure of a powerful economic group, ${ }^{75}$ lends encouragement to the view that greater procedural formality may not be without benefit to the administration itself. Administrative regulations based upon purely scientific determinations have met with a good reception in court ${ }^{70}$ although it should be pointed out that these have largely interpreted statutory provisions, by way of advice to affected parties and of direction to enforcement officers, rather then added to the law by virtue of delegated authority. They have been without binding force and hence are distinguishable from those here under discussion. ${ }^{77}$ Regulations of a scientific nature under the Food and Drugs Act of rgo6 have been of this interpretative variety. ${ }^{78}$ They, if not all acts of the administration, ${ }^{78}$ have been upheld by the courts. ${ }^{80}$

Regulations appraising the qualities of products in terms of human estimation of them present a more difficult procedural problem. The properties that are valued, for example, in a canned fruit depend upon subjective and customary considerations.

facts and a greater element of judgment in the final conclusion, would present a more difficult procedural problem. Such was the situation in relation to the Interstate Commerce Commission's investigation of the need of locomotive power reverse gears in the interest of safety, involved in U. S. v. Baltimore \& Ohio R. Co., 293 U. S. 454 (1935). In the proceeding before the Commission the testimony of numerous enginemen and lay witnesses was received. Johnson v. Atlantic Coast Line R. Co., I90 I. C. C. 35I (1933), 222 I. C. C. 542 . In connection with the judicial review of such proceedings unexpected difficulties may occur, caused by the unavoidable naĩveté of a judge not versed in the subject matter. Following the overturning of the Commission's order in both the district court and the Supreme Court, the Commission pointed out that the district judge had not understood that reverse gears are used for their braking effect in regular operation and not merely for the purpose of reversing direction. 222 I. C. C. at 554-555. No doubt this fact had been assumed by all parties and had not been stated in the record.

${ }^{\pi}$ Dep't of Agr. Release 420-39, Sept. 20, 1938, announced an increase in the tolcrance of lead spray residue on fresh fruit from .018 grain to .025 grain per pound. The action of the Secretary of Agriculture was said to be based upon advice from the Public Health Service that an uncompleted investigation of the effects of lead poison upon human beings had not yielded evidence that the increased quantity would be harmful. Assuming that some affected interest were in a position to challenge a similarly unsupported order in court under the new Act, it is safe to say that it would be overturned without ceremony, if, indeed, it were entered in the first place.

${ }^{70}$ U. S. v. Bertram Bros., I3I Fed. 833 (Ig04); Commercial Solvents Corp. v. Mellon, 277 Fed. 548 (App. D. C. 1922); Knapp v. Callaway, 52 F. (2d) 476 (S. D. N. Y. I931).

"See p. 44, stipra.

"Thayes \& Ruff, The Administration of the Federal Food and Drag Act (1933) I Law \& CoNtemporary Problems, 16, 20; U. S. v. Antikamnia Chemical Co., 23 I U. S, 654 (r914).

${ }^{79}$ U. S. v. Ten Cases, More or Less, Bred Spred, 49 F. (2) 87 (C. C. A. 8th, I931); Van Camp Sea Food Co. v. U. S., 82 F. (2d) 365 (C. C. A. 3d, x936); U. S. v. Washington Dehydrated Food Co., 89 F. (2d) 606 (C. C. A. 8th, 1937).

${ }^{20}$ U. S. v. Antikamnia Chemical Co., supra note 78; U. S. v. Five One-Pint Bottles, ctc., 9 F. Supp. 990 (S. D. N. Y. 1935). 
These are not capable of scientific or expert determination, but each must be estimated on the basis of a consensus of lay opinion. Many properties must be considered in arriving at a conclusion in regard to the quality of any product: If the investigational procedure is to be formalized, issues must be framed, expressly or by implication, with respect to each property; evidence must be incorporated into a record with regard to each; and findings upon each must be stated. Judicial review may then check upon the support which the findings have in the evidence. Here a more wide-ranging inquiry, involving more complex issues than a simple scientific investigation, obviously is called for..$^{81}$ Whether formal administrative methods are likely to succeed in this field depends largely upon the practicability of analyzing the problem under investigation into constituent parts that can be treated in the manner indicated. Whether judicial review is likely to be helpful or obstructive will be discussed below. ${ }^{\mathbf{2}}$

Regulations that must take account of psychological effects, such as the impressions made by labels and by directions for the use of products, also involve investigations designed to elicit information from lay sources, at least in part. Presumably the issues are somewhat simpler than in cases where quality standards are sought, however. The necessary size of type in a warning notice, the reaction of consumers to the phrasing of proposed statements in regard to inferior quality, ${ }^{83}$ and the like, present fairly definite questions that may.be stated, looked into, and answered by legal methods. The answers, however, are likely to represent almost intuitive conclusions based upon rather subtle considerations. Judicial review necessarily will deal largely with the justification for the conclusions, and reversals are likely to be based upon the allegedly arbitrary and capricious character. of the conclusions, rather than upon insufficiency of the evidence to support the findings or upon errors of law. ${ }^{84}$ Again, the courts must exercise self-restraint if judicial review is to remain within its proper sphere.

In estimating the probability of the success or failure of the procedural and review

Analogous differences in the character of the inquiries and the types of judicial review that are adapted to various problems exist in the field of rate-fixing and have been recognized, although not clearly, by the courts. Where utilities have a heavy capital investment which may be "confiscated" if an adequate return is not permitted, and the "value" of which presents an issue to which proof can be addressed, the possibility of complete judicial review of the administrative determination of value, including the reception of additional evidence in court, has been held to be constitutionally necessary where the question of confiscation is raised. St. Joseph Stockyards Co. v. Wallace, 298 U. S. 38 (I936). Where, on the other hand, the value of services rendered without important capital investment presents a less clear-cut issue, in which the question of confiscation is not said to be involved, a less minute judicial review, giving more conclusiveness to the judgment of the administrative authority, satisfied the requirements of due process. Acker v. U. S., 298 U. S. 426 (1936). In the same class of case, however, it has been held that the administrative procedure must provide for a framing of issues to which arguments may be addressed, where the deciding officer is different from the one who receives the evidence. Morgan v. U. S., 304 U. S. I (1938). Recent cases in other courts than the Supreme Court present a somewhat confused picture, both recognizing the complex and wide-ranging nature of the inquiry involved in the fixing of prices or wages for numerous enterprises in a single proceeding and tending to insist upon the procedural safeguards to which the Supreme Court has directed attention. Colteryahn Sanitary Dairy v. Milk Control Commission, r A. (2d) 775 (Pa. 1938); Western Union Tel. Co. v. Industrial Comm'n, 24 F. Supp. 370 (D. Minn. I938).

See p. 58, infra.

${ }^{\infty}$ See p. 62, infra.

${ }^{84}$ See p. 6r, infra. 
provisions of the new Food, Drug, and Cosmetic Act in connection with the foregoing classes of regulations, account should also be taken of certain influencing factors that cut across the boundaries of these classes. In the first place, the requirement of the Act that hearings be held on the basis of definite proposals of regulations ${ }^{85}$ should result in a better advance understanding of the issues and in greater relevance of the testimony to them. Hence the procedure should be more workable because of this requirement than it otherwise would be. ${ }^{80}$

In the second place, the rule-making proceedings of the Food and Drug Administration may of course be conducted with at least that degree of freedom which characterizes practically all administrative processes ${ }^{87}$ and probably with considerably more than is permitted in a number of other fields. Pleadings, as well as the technical rules of evidence prevailing in the courts, may be dispensed with. In addition, where numerous parties are affected by a proposed order, it is not necessary that the evidence in the record deal specifically with the affairs of each. ${ }^{88}$ In considering numerous procedural questions that may arise it is unlikely that the courts, with whom will rest the task of defining the minimum formal requirements, will ignore the consideration that the proceedings remain "quasi-legislative" 80 or fail to admit occasional recourse to the analogy of legislative methods. To some extent counterbalancing this factor is the provision of the Act that all interested parties are entitled as of right to be heard in the prescribed manner, ${ }^{90}$ thus rendering impossible the summary methods that prevail, for example, in the assessment and collection of property taxes in the states. ${ }^{91}$

\section{EXPERIENCE UNDER the MCNARY-MAPes AMENDMENT}

There exists one body of experience under the prior food and drug legislation to indicate the possible working of the procedural and review provisions of the new Act. In r930 the so-called McNary-Mapes Amendment was adopted, conferring upon the Secretary of Agriculture the power to promulgate a minimum standard of quality, condition, and fill of container for each class of canned food coming under the Act, together with a form of statement to appear upon the labels of cans falling below such standards. Cans not meeting the standards nor bearing the proper labels were to be treated as misbranded. ${ }^{92}$ The same provisions, applied to all foods with a few exceptions, are carried forward into the new $\mathrm{Act}^{23}$ and constitute one of the rule-

\footnotetext{
$\$$ §70I (e), 2I U. S. C. $\$ 37$ I (e).

${ }^{8 s}$ In an earlier form, in which proposals not only were permitted from private sources but hearings upon them were made mandatory, this provision was condemned on non-procedural grounds as obstructive of the administration of the Act. H. R. REP. No. 2139, 75th Cong., 3d Sess. (1938), Pt. 2 (Mlinority Views) p. 2.

8T Note (1932) 80 U. of PA. L. Rev. 878; Hanft, Utilities Commissions as Expert Courts (1936) 15 N. C. L. REv. I2.

${ }^{8}$ Beaumont, S. L. \& W. R. Co. v. U. S., 282 U. S. 74 (1930).

${ }^{\circ} \mathrm{Sec}$ note 64 , supra. Thus there is ground to believe that cross-examination may be largely avoided.

${ }^{\infty 0} \$ 701(\mathrm{c}), 2$ I U. S. C. $\$ 37 \mathrm{I}(\mathrm{c})$.

or Bi-Metallic Inv. Co. v. Colorado, 239 U. S. 441 (I915); Columbia Terminals Co. v. Koeln, 3 I9 Mo. 445,3 S. W. (2d) ro2I.

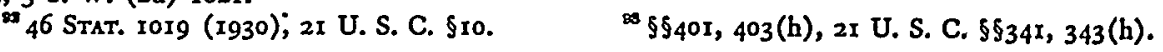


making powers whose exercise has been discussed. The McNary-Mapes Amendment contained no provisions for the procedure to be employed in the promulgation of regulations or for judicial review of the departmental measures. ${ }^{94}$ Nevertheless its administration has presented many of the problems that will arise under the more detailed terms of the new Act.

A prominent factor in the administration of the amendment has been the presence of a strong economic interest in back of the law. The McNary-Mapes measure was sponsored by the National Canners' Association ${ }^{95}$ and its passage was hailed as "the culmination of practically two years' effort on the part of the canning industry." "The purpose of the effort was clear. It was to eliminate competition between "standard" and "sub-standard" canned goods and even, if possible, to drive the sub-standard product off the market by means of a forbidding, or "crepe," label.97 A leading trade paper was confident that "Walter Campbell, chief of the Enforcement Division having charge of this new amendment to the Pure Food law, . . . is not a namby-pamby, milk-and-water sort of man, but a red-blooded Kentuckian who will demand plain, truthful statements" on labels. ${ }^{98}$

The proponents of the measure recognized at times, however, that the sub-standard products which were to be labeled as such were not unwholesome and that the label must avoid the danger "of leading consumers to think that these low-grade goods are not good to eat, not safe and wholesome, when as a matter of fact they must be wholesome and pure or the department would not permit them to be sold." Food and Drug Administration itself asserted that "While it may have been the purpose of some of the advocates of this measure to make sub-standard canned goods so unpopular they would be driven off the market," there was no evidence that such was the intention of Congress and it was not the Department's conception that the label should stigmatize the product. ${ }^{100}$

Although not obliged to do so under the law, the Food and Drug Administration announced a hearing in Washington upon certain proposed standards for canned peas, peaches, and pears and upon a proposed sub-standard label. ${ }^{101}$ Transcripts of the hearings were prepared. Informal discussions were also held with the members of the industry who were in attendance at the convention of the National Canners' Association in Chicago in January, 193I, reports of which were prepared for the use of the Food and Drug Administration. ${ }^{\mathbf{1 0 2}}$ Previously suggestions had been received

\footnotetext{
or Senator Copeland introduced an amendment to the measure, which was adopted by the Senate, providing for a food standards committee to formulate the standards after hearings, subject to review by the Secretary of Agriculture. 72 CoNG. REc. 10166 (1930). The amendment was eliminated in conference. H. R. Rep. No. 2027 , 7oth Cong., $2 d$ Sess. (x930).

${ }^{\text {(I930) }} 52$ CANning TRAde, No. 27, Pp. 56-57; Hearings before the House Committee on Agriculture on $H . R$. 1521 $\delta$, 7oth Cong., 2d Sess., Jan. 30, r929.

The Canner, July 12, 1930 , p. 18.

${ }^{\infty}$ Id., No. 7, p. 8 (1930).

"I (193r) 53 Canning Trade, No. 28, p. 9.

${ }^{\infty}$ Id., No. 18, p. 9 (1930).

${ }^{100}$ Address of Paul B. Dunbar, Ass't Chief of the Food and Drug Administration, before the National Canners' Ass'n, Jan. 19, 1931, 53 Canning 'Trade, No. 26, p. 34; statement of W. G. Campbell, Chief of the Food and Drug Administration, Dept. Agr. Release, Sept. 5, 1930.

${ }_{101}$ Notice, dated Dec. 2, 1930, of hearing on Dec. 15, 1930.

${ }^{100}$ Report of Dr. W. B. White, Chief of the Food Division, on file in the Division.
} 
by the Department from various sources. Those concerning the sub-standard label were summarized in a typewritten office memorandum. ${ }^{103}$ By these means, although no complete record was made, interested parties were heard'and information was gathered and preserved for use in the preparation of the regulations. Later proposals for regulations under the amendment were subjected to consideration in a similar manner. ${ }^{104}$

The effect of matter brought to the attention of the administration by these means is apparent in the action taken with respect to food standards. The initial regulations ${ }^{105}$ were considerably more lenient than the proposals originally made. In I93I the percentage of solid tomatoes required under the promulgated standard was made $45,^{106}$ as compared to a proposed 40 in the announcement of the hearings. ${ }^{107}$ At a number of the sessions the discussion by members of the canning industry was spirited and to the point and reflected a sincere desire to further good standards. The Administration attempted from time to time to draw expressions of opinion from the consumer representatives who were present.

But, as might have been expected, the wording of the sub-standard label provided the most important bone of contention during the consideration of the regulations and the best illustration of the operation of the procedure under the McNary-Mapes Amendment. In addition, the label has been challenged twice before the courts. The Food and Drug Administration originally proposed a label bearing the legend, "Below U. S. Standard: Legal-Wholesome." Representatives of the canning industry who attended the hearing contended that the words "legal" and "wholesome" gave the impression of governmental endorsement to the sub-standard product and urged that they be replaced. ${ }^{108}$ One representative urged frankly that the Administration adopt "some legend that will be a sales-resistance factor." Although the Chief of the Food and Drug Administration emphasized twice during the hearing that the label should not stigmatize the product, the National Canners' Association was assured a month later that the legend finally approved would not include the words, "legal" and "wholesome," but that other words qualifying the phrase, "below U. S. Standard," would be used.110 The initial regulations as they later appeared prescribed "Below U. S. Standard: Low Quality but not Illegal" as the wording of the sub-standard legend.111 Canning Trade shortly afterward reported that "As a matter of fact, the proponents of this law expect that this legend will entirely drive out of the

${ }^{100}$ Nov. 21, 1930 (on file in the Food Division of the Food and Drug Administration).

${ }^{201}$ Hearings in Washington, D. C., April 13, 1931, and in San Francisco, April 14, upon proposals for standards for canned tomatoes, cherries, and apricots; hearings in Washington, D. C., April 14, 1932, upon proposed changes in standards and in the sub-standard label; hearings in Chicago, Jan. 18, 1935, on stricter standards for canned tomatoes, mushrooms, and cherries; hearings in Chicago, Jan. 26, x937, on standards for canned red sour pitted cherries; notices and requests for written comments upon miscellaneous changes, April 21, 1933, April 30, 1934, Feb. 20, 1935, and April 21, 1937.

${ }^{105}$ Dep't Agr., Service \& Regulatory Announcements, F. \& D. No. 4, xst Rev., Feb. 16, 1931.

${ }^{100}$ Id., April 27, I93I.

${ }^{100}$ Transcript of hearings, Dec. 15, 1930, pp. 8-20.

${ }^{200}$ Id., pp. 12-13. See also (1931) I2 Canning Age 35.

${ }^{10}$ Address of Paul B. Dunbar, supra note zoo.

III Service \& Regulatory Announcements, supra note ro5.

${ }^{10 \pi}$ See note $\mathrm{Y04}$, supra. 
market all canned foods which must appear under it. In other words, they expect this legend to kill the packing of sub-standard canned foods." The comment was added that "We believe Dr. Dunbar and his assistants are to be congratulated upon the wording, the manner of display, and the size of the legend requirement. From that point of view it ought to be effective."112

The Administration, however, was subject to continuing doubts regarding the fairness of the prescribed label. Early in 1932 it announced a hearing in Washington upon a proposed substitute, reading "Below U. S. Standard; Good Food-Not High Grade." 113 The hearing was attended by approximately 70 persons, including two representatives of the Bureau of Home Economics and two representatives of consumer organizations. The Department sought particularly to elicit the reactions of the consumer representatives to the alternative legend, expressing also its own view that the label should not prevent the marketing of wholesome products. The only definite reaction obtained was favorable to the proposed substitute as being more enlightening and less forbidding. ${ }^{114}$ The canners' representatives who were present, as one of them put it, "generally are asking that this legend be changed on fruit but left as it is on canned vegetables." 115 It appeared from the testimony that avoidable delay in the picking of vegetables for canning and careless methods of packing had been widespread in the industry; that the regulations in force in I93 I had minimized such practices, ${ }^{116}$ and that a change of label which would reopen the market to substandard products would lead to a prompt resumption of careless methods. In fruit canning, on the other hand, deficiencies in size, perfection of fruit, and other elements of quality were less avoidable and less objectionable to consumers, so that a label which would be informative but not forbidding was thought to be desirable. The view was expressed by the Administration, moreover, that the labels, required because of certain deficiencies, might well be so drawn as to specify the precise nature of the departures from standard. ${ }^{117}$ In the revised regulations which shortly afterward appeared ${ }^{118}$ the proposed alteration in the label was introduced as to canned fruit and the former legend was retained as to vegetables. Specification of certain departures from standard, relating largely to the appearance of the various products, was also permitted. In 1937, apparently without preliminary hearings, the previous substandard legend for fruit, substituting "Good Food-Not High Grade" for "Low Quality but Not Illegal," was applied also to vegetables. ${ }^{119}$

112 (193I) 53 CanNing Trade, No. 28, p. 9.

${ }^{113}$ Notice, dated Mar. I8, 1932, of hearing in Washington, D. C., April 14, 1932.

${ }^{214}$ Transcript of hearing, p. 21.

${ }^{115} I d .$, p. 23. See also (1932) is Canning Age 286.

${ }^{110}$ See also Dep't Agr. Release, Oct. I, 1931, containing a statement by D. M. Welch, Chief of the Baltimore Station of the Food and Drug Administration, to the effect that "Packers were unusually careful in putting up canned tomatoes this season, as they have found no market for the substandard product to date. Having been notified of the provisions of the Mapes amendment, the canners were careful to put up a pack that would not require the substandard labeling."

${ }^{117}$ Transeript, satpra note II 4 , at 69 .

${ }^{28}$ Dep't Agr., Service \& Regulatory Announcements, F. \& D. No. 4, 2d Rev., Aug., 1932.

${ }^{10}$ Id., $4^{\text {th }}$ Rev., Sept., 1937. 
Shortly after its promulgation, the original requirement of the sub-standard legend was challenged as it applied to sliced peaches whose sole departure from standard lay in a lack of uniformity in the size of the slices. ${ }^{120}$ The plaintiff sought an injunction against the seizure as misbranded of several thousand cases of the peaches to which the required label had not been affixed, contending that the wording of the label was arbitrary and in excess of the authority delegated in the legislation. That authority, it was alleged, extended no farther than to permit the requirement of "such a label as would fairly indicate the respect in which the peaches fail to comply with the standard promulgated." In defense of the suit the government filed affidavits reciting the efforts of the Administration to gather evidence upon which to base its regulations, setting forth the conclusion that uniformity in the size of slices was considered by the trade to be an element in quality, and containing opinions of individual canners to the same effect. The Secretary of the National Canners' Association deposed that the required label "is truly descriptive and informative of the quality of sliced canned peaches which are not uniform in size."121 The court denied the injunction without opinion. Six years later the Administration dispensed with the requirement of even its softened sub-standard label upon canned peaches which "fail to meet the standard of quality and condition only in that they are not uniformly sized" and permitted the substitution of the legend, "Peaches, Ungraded for Size."122

The only other challenge in court to the McNary-Mapes regulations was offered in an action to restrain the enforcement of the labeling requirement against canned soaked, dried peas, which were sub-standard by reason of not having been canned in an immature state as required by the regulations as revised in $1932,{ }^{123}$ which also required the addition of the statement, "Soaked dried peas" to the regular substandard label.124 Certain canners, notably the plaintiff itself, had in a few years built up an annual business of between 200,000 and 250,000 cases of canned soaked peas. These bore the legend, "Prepared from Dried Peas," and were sold throughout the country at lower prices than canned fresh peas and in competition with them. The pea canning industry was aroused by this development. "Away with the old blurb that Soaked Peas are good food," demanded Canning Trade. ${ }^{125}$ Just after the institution of the Morgan Company's action the Pea Section of the National Canners' Association requested the Food and Drug Administration to "actively enforce the regulation covering this product."126

The evidence in the Morgan case showed without contradiction that soaked dried peas are a wholesome food, usually not less tender than the minimum permitted for canned fresh peas under the standard, but mealy in character, producing a cloudy

${ }^{200}$ F. Clemens Horst Co. v. Hyde (N. D. Calif., I93I) (unreported).

120 Typewritten transcript of evidence, on file in the Food and Drug Administration.

20 Service \& Regulatory Announcements, supra note Ir8, p. 5.

123 The regulation complained of was promulgated May 25, 1932, and became effective in August. 1d.

${ }^{234}$ Morgan v. Nolan, 3 F. Supp. $x 43$ (S. D. Ind. 1933), 69 F. (2d) 47 I (C. C. A. 7th, 1934).

100 (1932) 55 CANNING TrADE, No. 3, p. $6 . \quad$ Idd., no. 28, p. 48 (1933). 
liquid, and somewhat different in taste, and that the product was marketable only in small quantities when it bore the government's "crepe" label. ${ }^{127}$ Again the government recited its efforts to obtain information from all interested parties before adopting its regulations. It proved that the plaintiff had been sent a notice of the hearing upon the proposed regulation relating to soaked dried peas, together with a copy of the proposal, and had failed to appear at the hearing or to interpose written objections.

District Judge Baltzell was suspicious of trade opinion as a basis of official regulations and demanded facts to sustain the regulation. ${ }^{128} \mathrm{He}$ wished to know what the statements in the legend, going beyond the information that the product was soaked dried peas, added to the information furnished to the consumer. Informed by a government witness that the consumer received a warning of low quality, as the statute intended, he suggested that the legend "is well calculated" to "cause suspicion in the mind of the consumer, isn't it?" The answer was, "It might be."129

The district court held that the prescribed label was unreasonable because destructive of trade in a legitimate product; that canned soaked peas were a different "class of food" from canned fresh peas; and that a different set of regulations should be applied to the two classes. The injunction issued and the decree was affirmed by the Circuit Court of Appeals. The Administration shortly afterward undertook to promulgate separate standards and labeling requirements for soaked dried peas in accordance with this view..$^{130}$

The handling of the labeling requirement under the McNary-Mapes Amendment is an example, clearly, of administration not functioning in a sound and effective manner in certain respects. Because of pressure from economic interests, the regulations originally adopted apparently did not represent the real convictions of the administration. In the case involving sliced peaches, by later tacit admission, an unjust labeling requirement, subsequently abandoned voluntarily, was enforced against a canner to his great loss after having been supported by the manifestly absurd opinion of an interested affiant that the statement, "Low Quality, but Not Illegal," correctly described fruit whose sole deficiency was irregularity in size. Only after six years, following a defeat in court, was a thoroughly fair and effective set of labels prescribed.

In the Morgan Company case the device of judicial review appears to relative advantage. The trial court penetrated shrewdly to the heart of the controversy and rendered an apparently just decision. On the other side it might be contended that in reality canned dried peas were fraudulently substituted for canned fresh peas in retail sales and that the Administration, knowing that fact but being unable to prove it, had rightly struck at the practice by the only method possible, namely, stopping at its source the product that was susceptible to deceptive marketing. Such indirect

\footnotetext{
277 Typewritten transeript of evidence, on file in the Food and Drug Administration.

${ }^{128}$ Transcript, pp. 98-100, 107. ${ }^{100}$ Id., I61, I75.

${ }^{130}$ Notice of Feb. 20, 1935. Revised regulations for peas were promulgated May 8, 1936.
} 
methods of law enforcement are not, however, seriously recommended in any responsible quarter.

It is interesting to consider whether the procedure provided in the new Act is likely to work an improvement in rule-making methods and in judicial review of regulations having to do with standards and labeling. Much bulkier and more expensive administrative records clearly will have to be made. Evidence will have to be introduced upon each constituent element in the quality of a class of food that is to be subjected to a standard. The effects of labels upon persons reading them will have to be established by adequate opinion evidence, if not by expert testimony. The task is likely to be exacting and long drawn-out. The gauntlet of judicial review will have to be run more frequently and with wider reviewing powers on the part of the courts. Counterbalancing the difficulties in the foregoing scheme, there will be the possibility and even the necessity of resisting pressure from interested groups except in so far as it is adequately supported by facts. More clearly-reasoned conclusions may result from improved analysis of the problems to be solved. Injustice in particular cases may be avoided more successfully. Realistic judicial review may be furthered by the more adequate records with which the courts will be confrontedunless the absence of direct contact with the witnesses militates too greatly against shrewd judicial appraisal of the situations presented. In an ideal world, with officials free to pursue the public interest which they had at heart, simple, informal administration would be preferable; in the world of today, with groups pulling officials powerfully in the direction of their advantage, procedural formality in the type of rule-making exemplified under the McNary-Mapes Amendment seems likely to promote good administration-provided the administrative machine is sufficiently enlarged to carry the load, and provided further that the courts exercise their powers of review with appropriate restraint.

Judicial review under the new statute presents an additional difficulty which must be met if the Act is to function successfully. In Morgan v. Nolan, as in most other cases of attack upon administrative regulations of a general nature, the object of the suit was to restrain the application of the regulation to the plaintiff, and the judgment did not extend beyond that purpose. The reasonableness of the label requirement as applied to the plaintiff's product presented a fairly narrow issue, upon which the court could pass by following its usual methods. Had the question related instead to the reasonableness of the label requirement wherever it applied, a very different type of issue would have been presented. It is that type of issue which will normally be presented when a regulation is challenged in court under the provisions of the new Act, for the appeal seems intended to bring up the order as a whole. Only if the courts limit themselves strictly to detecting serious flaws in the administrative reasoning, without themselves attempting to check the administrative conclusions upon such general matters in the light of reasoning of their own, will the scheme of review be workable. Even then it gives rise to constitutional doubts. 
VI. Legal Problems Connected with Judicial Review

\section{A. The Constitutionality of Judicial Review of General Regulations}

Several problems of a legal nature are raised by the judicial review provisions of the Food, Drug, and Cosmetic Act. One of these, the question of the constitutionality of judicial review of general regulations and particularly judicial prescription of affirmative action by the administrative authorities, goes to the heart of the rulemaking process and of the function of the courts in relation to administrative action. The Act provides ${ }^{131}$ that the courts shall have jurisdiction to affirm or set aside orders in whole or in part and, further, that "if the order of the Secretary refuses to issue, amend, or repeal a regulation and such order is not in accordance with law the court shall by its judgment order the Secretary to take action, with respect to such regulation, in accordance with law."

So far as the words of the Act are concerned, the power to affirm or set aside orders is no broader than that conferred in other statutes ${ }^{\mathbf{1 3 2}}$ which provide for the judicial review of administrative action. As previously noted, however, ${ }^{183}$ prior statutes of this nature provide for review of orders that are addressed to particular parties, rather than general regulations. An affirmance of such an order is simply a holding that the legal rights of these parties have not been infringed; a reversal in whole or in part is based either upon a violation of those rights or upon an excess of power which invalidates the order as against the only persons to whom it applies. Orders under the new Act, on the other hand, embody regulations that are general in scope. To affirm or set aside such an order is to pronounce incidentally upon the rights of many persons not party to the suit. ${ }^{134}$ Nevertheless, the Act contemplates a limited range of issues affecting the orders of the Secretary, upon which the courts are to pass: (I) the presence of evidence to support the findings of fact; (2) the power of the Secretary to act at all; (3) the conformity of the administrative procedure to the requirements of the statute; and (4) the possible presence of arbitrariness or unreasonableness in the administrative conclusions. ${ }^{135}$ Except for the lastmentioned issue, these are fairly definite questions which, even when they arise out of an essentially non-judicial administrative proceeding, are recognized as susceptible to judicial determination at the suit of an interested party. No reason appears why they may not be determined by the courts when they arise out of rule-making proceedings.

The last issue presents both practical and constitutional difficulties. Its determination affords a vehicle for the extension of judicial review to matters which should be determined finally by administrative experts, if a court chooses to brand as arbitrary

$20 r \$ 701(f)(3), 2 x$ U. S. C. $\$ 371(f)(3)$.

20a see note 50, supra.

120 See p. 49, supra.

${ }^{234}$ It would be otherwise in certain cases if the courts should undertake to direct the modification of orders as applied to particular plaintiffs only. See p. 68 , infra.

${ }^{25}$ Fuchs, Concepts and Policies in Anglo-American Administrative Law Theory (1938) 47 YaLE L. J. $538,555-556$, and works cited. 
or unreasonable ${ }^{136}$ a conclusion of theirs with which it simply disagrees. Even where conclusions are based upon findings of fact scientifically arrived at and hence are subject to a minimum of procedural difficulty, ${ }^{137}$ the possibility, if not the probability, exists that there may be unwarranted judicial" interference in the outcome. ${ }^{138}$ It is likely, however, that judicial self-restraint will operate, in this field, ${ }^{130}$ to limit judicial review to its proper scope.

${ }^{10}$ An alternative device for extending judicial review is the branding of a conclusion as one of law because it is a conclusion called for by a statute, thus subjecting it to judicial review despite the fact that it is properly a matter for expert determination. Federal Trade Comm'n v. Gratz, 253 U. S. 421 (r920), holding that the nature of "unfair methods of competition" under the Federal Trade Commission Act presents in the last analysis a question of law for the courts.

$18 \pi$ See p. 53, supra.

239 The procedure under the Ig06 Act was conducive to the substitution of judicial for administrative judgment upon essential conclusions, which were not, however, embodied in regulations. In U. S. v. Washington Dehydrated Food Co., 89 F. (2d) 606 (C. C. A. 8th, 1937), the question was whether the district court, sitting without a jury, had rightly decided a libel proceeding, involving certain sacks of "apple chops" alleged to be aduiterated by reason of the presence of added arsenic and lead poison, in favor of the owners. The "chops" were dehydrated apple cuttings, intended for use in the manufacture of apple butter. They contained an ascertained amount of poisonous spray residue from the raw apples. The question under the Act, \$7, was whether the chops contained "any added poisonous or other delcterious ingredient which may render such article injurious to health." The evidence as to the quantity of poison was clear and the harmful effect of lead and arsenic upon human beings was not disputed. The expert opinion evidence differed sharply, however, upon the precise effect of the consumption of the indicated quantities of these poisons when contained in apple butter and other foods. The trial court found "That the apple butter into which the apple chops in this case would be manufactured would not have an arsenic or lead content which might render the apple butter injurious to health; that the apple butter would not be adulterated within the Food and Drug Act." The Circuit Court of Appeals treated this finding as one of fact, pointed out that the burden of proof at the trial rested upon the government, and declined to interfere with the outcome. Actually, however, the most essential fact remained in doubt and was scttled for the purposes of the case only by reason of the incidence of the burden of proof and the effect of the evidence upon the mind of the trier of fact. The real issue in such matters is whether in the light of the ascertained facts and of the probabilities under conflicting evidence, the conclusion is justified that the product should be treated as adulterated. At times, even when all the facts are clear, a question of policy remains which must be similarly determined. The evidence may be clear that certain poisons have certain deleterious effects which, however, are infinitesimal in ordinary persons. The issue then takes the form of whether there is economic justification for subjecting consumers to the risk of absorbing such quantities of poison- "not . . . a disputed issue of fact, but rather a difference . . . over the meaning of the words, 'deleterious ingredient, injurious to health.'" W. B. Wood Mfg. Co. v. U. S., 286 Fed. 84 (C. C. A. 7th, 1923). Under the new Act such issues are for administrative determination in the proceedings which lead to the issuance of regulations. These determinations are not to be overturned except when they are clearly arbitrary and unreasonable or when supporting findings are unsupported by any substantial evidence. The burden of proof which has rested upon the government in such cases has been removed. Certain interests sensed while the bill was in Congress that such would be the case under the new law. Hearings before the Senate Committee on Commerce on S. 5, 74th Cong., Ist Sess. (1935) 266-271. They suggested that in a criminal proceeding for violation of a regulation the Government be required "to prove its case affirmatively in the first instance and that the regulation alleged to have been violated is in accord with the facts and the law." Testimony of R. G. Phillips, Secy., International Apple Ass'n, Hearings before the House Committee on Interstate and Foreign Commerce on S. 5, H. R. 6906, H. R. 8865, and $H . R .894 I$, 7th Cong., Ist Sess. (1935) 324. They were defeated in their final attempt to insure judicial re-examination of such issues. See p. 48 , supra. It is unlikely that the courts, under the statute as drawn, will restore the victory to them.

100 The bias against government experts in Judge Buffington's opinion in Van Camp Sea Food Co. v. U. S., 82 F. (2d) 365 (C. C. A. 3d, 1936), is not usual among judges in cases where matters of physical science are involved. See p. 54, supra. The learned judge minimized the credibility of the testimony of a Food and Drug Administration expert that certain sardines were somewhat decomposed, partly on the ground that it had not been shown that the sardines had not been allowed to stand in an open can for half a day in Washington's summer heat before being examinedl The decision reversing a judgment for the government, based upon a jury verdict, was, however, supported by additional reasoning. 
The question previously raised, ${ }^{140}$ of whether it is constitutional to repose in courts the duty of determining even the soundness of the reasoning leading to the conclusion that a general regulation should be promulgated, has been considered only in a few state cases. ${ }^{141}$ It turns under the Federal Constitution upon the question of whether the soundness of the methods of reasoning in so essentially "legislative" a proceeding can under Article III be made a matter of judicial determination. The closest analogies occur in rate cases involving rather numerous parties.142 Orders which are "arbitrary" and "capricious" because of defective reasoning undoubtedly may be set aside where only one or a few named utilities are involved. ${ }^{14 s}$ The decisions reversing orders in cases involving numerous parties are based, however, upon deficiencies in the administrative procedure rather than upon faults in the reasoning. ${ }^{144}$ The question of whether the courts can be compelled to check upon the reasoning in such cases can only be argued, rather than answered, at the present time. The desirability of permitting legislative experimentation with procedure and remedies, as well as with governmental control powers, furnishes the most plausible argument for sustaining this aspect of the new Act.

More difficult to sustain is the provision previously quoted, giving the courts power to order the Secretary to take affirmative action according to law. Inserted partly, no doubt, to overcome the effect of the "negative order" doctrine, whereby an administrative agency's refusal to act cannot be subjected to judicial review, ${ }^{145}$ the provision raises in an aggravated form the objections which contributed to the establishment of the doctrine in the first place, ${ }^{146}$ for it seems intended to cause the courts not only to direct that action be taken but also to specify what that action shall be. It is settled by now, if anything can be, that the federal courts cannot be asked to take or to direct discretionary action of an affirmative character, even where the procoed-

${ }^{20}$ See p. 63, supra.

14 In Nelson v. State Board of Health, 186 Mass 330, 7x N. E. 693 (1904), the court for practical reasons construed a statute in such a way as to avoid judicial review of health regulations. In Sterling Refining Co. v. Walker, I65 Okla. 45, 25 P. (2d) 332 (1933), the court held it to be a proper judicial function to pass upon the "validity, reasonableness, and justice" of oil proration orders.

${ }^{10}$ Acker v. U. S., 298 U. S. 426 (1936). See 2lso Oklahoma Cotton Ginners' Ass'n v. State, 174 Okla. 243, 5 I P. (2d) 327 (1935); Aetna Ins. Co. v. Commonwealth, 160 Va. 698, 169 S. E. 859 (1933); L. \& N. R. Co. v. Garrett, 23 I U. S. 298, 313 (1913).

${ }^{23}$ The valuation cases, insisting upon "cost of reproduction" as 2 major factor in the value of utilities" property, hold not only that such cost is cvidence of value but that it must be given consideration in 2rriving at the administrative conclusion. St. Louis \& O'Fallon R. Co. v. U. S., 279 U. S. 16I (1929). See, generally, Beuted, Valuation es a Requirement of Due Process of Law in Rate Cases (r930) 43 Harv. L. REv. 1249; Barnes, Federal Conats and State Regulations of Utility Rates (1934) 43 YAlE L. J. 417; (1936) 2r ST. Lours L. REv. I68.

${ }_{14}$ Morgan v. U. S., 298 U. S. 468 (1936), 304 U. S. I (1938).

16 An agency's refusal to act where 2 definite right to have it act exists, or its refusal to rescind an arbitrary order or rule, may, on the other hand, be reviewed. Intermountain Rate Cases, 234 U. S. 476 (xgr4); U. S. v. New River Co., 265 U. S. 533 (1924). See 2 Senerachn, The Interstate Comanerce Comanassion (1931) 4 ro-4r4.

${ }^{14}$ In Procter \& Gamble Co. v. U. S., 225 U. S. 282 (1912), the doctrine was based partly upon the view that for the courts to undertale to review negative orders would be to involve them in administrative action. 
ing affects only a single party. ${ }^{147}$ To impose upon them the duty to do so in so distinctly "legislative" a matter as the prescribing of general regulations seems clearly beyond the pale. So construed, the provision of the Act here under discussion would be destined to fall victim to the theory of the separation of powers. The Act's separability clause, ${ }^{148}$ coupled with the apparently non-essential nature of the provision in question, ${ }^{149}$ would insulate the remainder of the Act from the effect of such an outcome. Should the provision fall, Congress may, if it wishes, substitute review by the Court of Appeals of the District of Columbia, which is not a court whose jurisdiction is limited by the Supreme Court's interpretation of Article III, for review by the Circuit Courts of Appeals. ${ }^{150}$

An alternative possibility exists, however. The provision of the Act here in question may be construed to require merely that the courts direct that some action be taken according to law, the administrative refusal being deemed arbitrary. Such an interpretation would be supported by the intention of the House Committee in charge of the bill when it was pending to secure the full degree of judicial review that was possible under the Constitution, ${ }^{151}$ as well as by the doctrine that laws should be interpreted if possible so as to preserve their constitutionality. So limited, the provision probably does not impose administrative duties upon the courts. ${ }^{152}$ It is more likely that it will receive this interpretation and be sustained than that it will be declared unconstitutional.

\section{B. The Right to Apply for Review}

For the purpose, no doubt, of avoiding the constitutional obstacle to requiring advisory opinions from the courts, the Food, Drug, and Cosmetic Act authorizes judicial review of regulations only "in case of actual controversy," in an action brought by "any person who will be adversely affected."153 The question arises of who are the affected persons, injury to whose interests by a regulation is likely to present an "actual controversy." There can scarcely be a doubt in regard to producers whom the regulation directly controls. A state whose attempts at regulation on its own account may be impaired by an order may also be entitled to take an appeal. ${ }^{154}$

The capacity of consumers or their representatives to proceed in court is subject to greater doubt. Although competitors of persons who are favored by some types of governmental action seem now to have achieved the status of possible challengers

${ }^{21 \pi}$ Keller v. Potomac Electric Power Co., 26x U. S. 428 (1923); Federal Radio Comm'n v. Gencral Electric Co., 281 U. S. 464 (1930). Compare Federal Radio Comm'n v. Nelson Bros. Bond \& Mtg. Co., 289 U. S. 516 (1933); Sterling Ref. Co. v. Walker, supra note 141 .

${ }^{163}$ §901, 2 I U. S. C. $\$ 39 \mathrm{I}$.

100 The provision has the practical purpose of providing a means to compel the modification of a regulation upon request, where' a hearing has been had upon such a proposal and a refusal to act is arbitrary. See note 86 , supra. The sponsors of this type of proceeding no doubt thought it important, but it scarcely goes to the essence of the legislation.

${ }^{150} \mathrm{Katz}$, Federal Legislative Couts (1930) 43 Harv. L. Rev. 894. Sę A. B. A., Advance Procras and REPORTS (1938), stpro note I.

${ }_{150}$ Note (1934) 34 Coz. L. REv. 908.

251 See p. 50, supra.

$2005701(f), 21$ U. S. C. $\$ 37$ I (f).

${ }^{21}$ Hopkins Fed. Savings \& Loan Ass'n v. Cleary, 296 U. S. 315 (1935). 
of such action in court, ${ }^{155}$ the interest of consumers is of a less tangible, certainly of a less definitely pecuniary, variety. Although undoubtedly consutmers are "interested persons" entitled to be heard at the administrative hearing, ${ }^{156}$ recognition of their ability to present a controversy in court would involve a further development in judicial reasoning. Large users of railroad freight services have not been recognized as proper challengers of rate orders of the Interstate Commerce Commission. ${ }^{157} \mathrm{On}$ the other hand the Court of Appeals of the District of Columbia has tentatively accepted the view that coal consumers may challenge price-fixing orders of the National Bituminous Coal Commission. ${ }^{158}$ It is apparent, moreover, that a consumers' group might propose regulations to the Food and Drug Administration and bring about hearings on them. Under such circumstances it would seem unrealistic and needlessly traditional to deny the substantial interest of such a group in the outcome or the actuality of the controversy to which it would be a party if it asked for judicial review of unfavorable administrative action. Here, evidently, is a field for legal development in the recognition of interests as they present themselves in present-day society. The outcome awaits consumer activity and judicial decision.

\section{The Operation of Decisions upon Review}

A judgment of a circuit court of appeals pursuant to the Act, modifying or setting aside a regulation or ordering affirmative action, ${ }^{159}$ will undoubtedly determine conclusively as against the government the questions involved in the case-subject, of course, to possible reversal in the Supreme Court upon certiorari. ${ }^{160}$ The Act, however, specifies that the review which it provides "shall be in addition to and not in substitution for any other remedies provided by law."161 There may be some doubt whether this provision will be sufficient to preserve the remedy of injunction in preference to the administrative appeal, within the go days which the statute allows for an appeal. The doctrine that equitable relief may be had only in the absence of remedies at law, including statutory remedies, may operate to postpone the availability of injunction suits until the expiration of the statutory period. In the absence of the quoted provision of the statute, the previous equitable remedy might have been held to have been withdrawn. ${ }^{162}$ The decisions assert the exclusiveness of explicit statutory remedies, partly upon the ground that the legislature intended the provisions for them to be so construed. The provision of the statute in this instance

\footnotetext{
${ }^{235}$ Frost v. Corporation Comm'n, 278 U. S. 515 (1929); Sykes v. Jenny Wren Co., 78 F. (2d) 729 (App. D. C. 1935).

257 Alexander Sprunt \& Sons v. U. S., 28 I U. S. 249 (I930).

200 Saxton Coal Mining Co. v. Nat. Bituminous Coal Comm'n, 96 F. (2d) 517 (App. D. C. x938).

230 The constitutionality of requiring such judgments is assumed for the purposes of the discussion in this sub-section.

${ }^{100}$ The Act explicitly preserves review by certiorari nnder $\$ \$ 239$ and 240 of the Judicial Code. $\$ 70$ (f). (4), 2 I U. S. C. $\$ 37 \mathrm{I}(\mathrm{f})(4)$. $\quad{ }_{101} \$ 70 \mathrm{I}(\mathrm{f})(6), 2 \mathrm{I}$ U. S. C. $\$ 37 \mathrm{I}(\mathrm{f})(6)$.

${ }^{100}$ Sykes v. Jenny Wren Co., supra note 53, cert. denied, 296 U. S. 624; (1936) 45 YALE L. J. 934; Monocracy Broadcasting Co. v. Prall, 90 F. (2d) 42I (1937); American Sumatra Tobacco Corp. v. Securities \& Exchange Comm'n, 93 F. (2d) 236 (App. D. C. 1937). The rule here followed is closely related to that which requires the exhaustion of administrative remedies before resort to court. Myers $\nabla$. Bethlehem Shipbuilding Corp., 303 U. S. 4 (I938). See note (1935) 35 Col. L. REv. 230.
} 
clearly leaves the remedy by injunction available, at least after the time for statutory appeals has expired. ${ }^{163}$

Assuming that an "aggrieved" person has pursued unsuccessfully the statutory appeal from an order imposing a regulation, the question arises whether an injunction suit is still available to such a person or whether it is barred by the doctrines of res adjudicata or judicial estoppel. The question also arises whether, if a similar suit is brought thereafter by another party, the issues will be determined by the results of the prior appeal, under the doctrine of stare decisis. It seems unlikely that suits will be held to be thus foreclosed, for the questions upon an appeal and in an injunction suit are essentially different. In the former the question is whether a regulation as applied generally is invalid in whole or in part; in the latter it is its application to the plaintiff which is in issue. Just as legislation which has been sustained as constitutional may be unconstitutional as against particular parties, including the party that has challenged it on general grounds, ${ }^{164}$ so, it may be assumed, may a Food and Drug regulation be valid in general but invalid in some specific application. The appeal and the injunction suit are adapted to deciding the two classes of questions.

The strictness with which the doctrine of res adjudicata operates may vary with the field of administration. ${ }^{185}$ Heretofore it has not been applied with rigidity to defeat the government's efforts at Food and Drug enforcement. ${ }^{108}$ In view of the different issues presented in injunction suits as compared with those in statutory appeals, there seems little reason to suppose that either that doctrine or the doctrine of stare decisis will now operate to defeat the statutory policy of saving pre-existing remedies.

As against a party who has unsuccessfully taken an appeal from an order imposing a regulation, it is possible that the doctrine of election of remedies ${ }^{107}$ might be applied to bar a later injunction suit. It could be argued that an opportunity to introduce evidence in regard to the hardships of the regulation upon the plaintiff was afforded in the administrative proceeding, or would be afforded by the court through a remission of the case to the Secretary of Agriculture for the reception of such evidence, and that by prosecuting such an appeal to a conclusion the plaintiff was barred from resorting to further remedies. The argument assumes, however, that the remedy of appeal, as well as that of injunction, may be used to test a regulation as applied to a particular plaintiff. This assumption seems contrary to the intent of the statute.

10 In addition to a remedy by injunction suit, a person prosecuted for the violation of a regulation, may, of course, set up the invalidity of the regulation as a defense.

Ios Village of Euclid v. Ambler Realty Co., 272 U. S. 365, 395 (1926).

${ }^{100}$ U. S. v. Stone \& Downer Co., 274 U. S. 225 (r927). For a good discussion of the subject, see Southern Pac. Co. v. Van Hoosear, 72 F. (2d) 903 (C. C. A. 9th, 1934).

${ }^{100}$ Aycock v. O'Brien, 28 F. (2d) 817 (C. C. A. .gth, I928); U. S. v. Certain Bottles of Lee's "Save the Baby," 37 F. (2d) 137 (D. Conn. 1929). See, however, George H. Iee Co. v. U. S., 4 I F. (2d) 460 (C. C. A. 9 th, 1930).

For a more extended discussion of this problem, see Lee, The Enforcement Provisions of the Food, Drug, and Cosmetic Act, infra, at p. 83. Ev.

${ }_{107}$ U. S. v. Oregon Lumber Co., 260 U. S. 290 (1922). 
Not only does the saving of existing remedies appear to be designed specifically to preserve the means of protecting particular parties from illegal injury by otherwise valid regulations, but the statutory appeal is ill-designed for this purpose. Its use would necessitate the reception of detailed evidence regarding the affairs of particular parties at hearings supposedly devoted to general problems, as well as delays in the effectuation of the purposes of the Act while new evidence was being received and regulations were being reconsidered upon the remission of orders at the behest of parties who, perhaps, had not appeared at the original hearings through lack of notice - or of knowledge of the precise effect of what was being proposed. It would be a serious error to twist the appeal proceeding to such a purpose. In this view, the ability of an affected concern to pursue both an appeal and the remedy by injunction must be conceded.

\section{Conclusion}

Thus it is apparent that the new Food, Drug, and Cosmetic Act, partly because it embodies a tendency toward greater formality of procedure and broader judicial review than has been customary in connection with administrative rule-making, is replete with new administrative and legal problems. It raises a number of questions that cannot yet be answered. Essential to its sound application is the realization on the part of administrators and courts that the effective control of the traffic in food, drugs, and cosmetics to the extent laid down in the statute is the prime requisite to public satisfaction. Private interest has in this instance been accorded full safeguards. The crucial question is whether business enterprise in these fields can be harnessed more effectively than before to the service of the common welfare. 